\title{
Flotation-Spectrophotometric Determination of Mercury in Water Samples Using Iodide and Ferroin
}

\author{
Mohammad Saeid HosSEINI ${ }^{\dagger}$ and Hamid HASHEMI-MogHADDAM \\ Department of Chemistry, Faculty of Science, Birjand University, Birjand, P. O. Box 79, Iran
}

\begin{abstract}
This paper describes a simple and highly selective method for separation, preconcentration and spectrophotometric determination of trace amounts of mercury. The method is based on the flotation of an ion-associate of $\mathrm{HgI}_{4}{ }^{2-}$ and ferroin between aqueous and $n$-heptane interface at $\mathrm{pH} 5$. The ion-associate was then separated and dissolved in acetonitrile to measure its absorbance. Quantitative flotation of the ion-associate was achieved when the volume of the water sample containing $\mathrm{Hg}(\mathrm{II})$ was varied over $50-800 \mathrm{ml}$. Beer's law was obeyed over the concentration range of $3.2 \times 10^{-8}-9.5 \times$ $10^{-7} \mathrm{~mol} \mathrm{l}^{-1}$ with an apparent molar absorptivity of $1 \times 10^{6} 1 \mathrm{~mol}^{-1} \mathrm{~cm}^{-1}$ for a $500 \mathrm{ml}$ aliquot of the water sample. The detection limit $(n=25)$ was $6.2 \times 10^{-9} \mathrm{~mol} \mathrm{l}^{-1}$, and the $\operatorname{RSD}(n=5)$ for $3.19 \times 10^{-7} \mathrm{~mol} \mathrm{l}^{-1}$ of $\mathrm{Hg}$ (II) was $1.9 \%$. A notable advantage of the method is that the determination of $\mathrm{Hg}$ (II) is free from the interference of the almost all cations and anions found in the environmental and waste water samples. The determination of $\mathrm{Hg}$ (II) in tap, synthetic waste, and seawater samples was carried out by the present method and a well-established method of extraction with dithizone. The results were satisfactorily comparable so that the applicability of the proposed method was confirmed in encountering with real samples.
\end{abstract}

(Received September 22, 2003; Accepted June 9, 2004)

\section{Introduction}

Mercury is a toxic element that can be absorbed easily by humans and other organisms; thus, its occurrence in the environment is very harmful for all living organisms. ${ }^{1}$ The lakes, rivers, and coastal waters in vicinity of industries that are utilizing mercury in production are essentially the important indicators of environmental pollution. Due to the highly toxic nature of this element in both its inorganic and organic forms, the determination of such low levels of mercury in an aquatic environment is of great importance. Most common techniques that have been reported for the determination of total mercury in natural samples include inductively coupled plasma mass spectrometry (ICP-MS), ${ }^{2}$ inductively coupled plasma atomic emission spectrometry (ICP-AES), ${ }^{3,4}$ gas chromatography coupled to atomic absorption spectrometry (GC-AAS), ${ }^{5-7}$ cold vapor atomic absorption spectrometry (CV-AAS), ${ }^{8-11}$ atomic fluorescence spectrometry (AFS), ${ }^{12}$ anodic stripping voltammetry (ASV), ${ }^{13,14}$ and neutron activation analysis (NAA). ${ }^{15}$ These techniques are very expensive and suffer from many complicated processing steps. These drawbacks may be partly avoided by the flotation-spectrophotometry, which allows one to preconcentrate the trace elements in various materials. ${ }^{16-22}$ Recently, various procedures of this method have been applied for the determination of several metal ions considering their sparingly soluble ion-associates formed at the interface of aqueous/organic phases. ${ }^{23-27}$ They are suitable to treat a large volume of the sample solution and to achieve a high preconcentration factor. In addition, the organic phase is usually not contaminated and can be used again without any

$\dagger$ To whom correspondence should be addressed.

E-mail: MSHosseini@birjand.ac.ir pretreatment process.

This paper deals with rapid separation, preconcentration and spectrophotometric determination of low level of mercury in aquatic samples by a simple flotation method in which the anionic mercury iodide complex is strongly associated with ferroin as a cationic dye reagent.

\section{Experimental}

\section{Materials and instrumentation}

All the reagents were analytical grade obtained from Merck, Germany. Double distilled water was used in all experiments. The stock solution of $1.6 \times 10^{-3} \mathrm{~mol} 1^{-1} \mathrm{Hg}$ (II) was prepared by dissolving an appropriate amount of $\mathrm{Hg}\left(\mathrm{NO}_{3}\right)_{2} \cdot \mathrm{H}_{2} \mathrm{O}$ in $0.14 \mathrm{~mol}$ $\mathrm{l}^{-1} \mathrm{HNO}_{3}$. The working solutions were prepared by dilution of this solution. The solution of $6.25 \times 10^{-3} \mathrm{~mol} \mathrm{l}^{-1}$ ferroin was made by sequential stoichiometrically dissolving of 1,10 phenanthroline (phen) and $\mathrm{FeSO}_{4}$ in an appropriate amount of water and adjusting its $\mathrm{pH}$ to 5 by using a diluted acetate buffer solution.

A Shimadzu Model 160 A spectrophotometer was used for all absorbance measurements with a $10-\mathrm{mm}$ quartz cell. A Corning Model $125 \mathrm{pH}$ meter was used for $\mathrm{pH}$ measurements.

\section{Procedure}

To an aliquot of a solution $(500 \mathrm{ml})$ containing up to $32 \mu \mathrm{g}$ of $\mathrm{Hg}^{2+}, 5 \mathrm{ml}$ of $0.12 \mathrm{~mol} \mathrm{l}^{-1}$ potassium iodide was added, and the $\mathrm{pH}$ was adjusted to 5 with the buffer solution. The solution was transferred to a $1000-\mathrm{ml}$ separating funnel; then $2.5 \mathrm{ml}$ ferroin and $40 \mathrm{ml} n$-heptane were added sequentially. The funnel was stoppered, vigorously shacken for $10 \mathrm{~min}$, then left to rest for a few minutes. As soon as the floating layer had settled at the aqueous/organic interface, both the upper organic and lower 


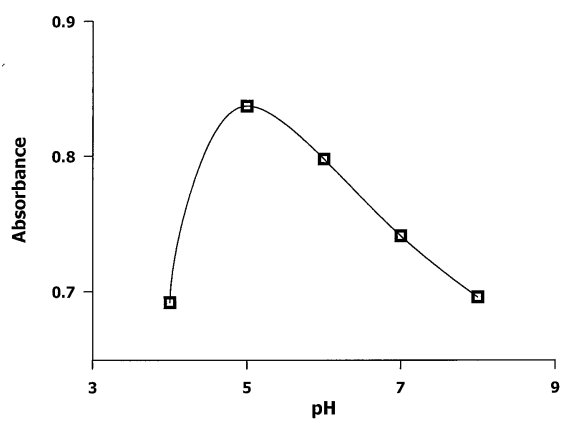

Fig. 1 Effect of $\mathrm{pH}$ on the flotation process at the conditions where: $C_{\mathrm{KI}}=1.2 \times 10^{-3} \mathrm{~mol} \mathrm{l}^{-1}, C_{\text {Ferroin }}=3.12 \times 10^{-5} \mathrm{~mol} \mathrm{l}^{-1}$, and $C_{\mathrm{Hg}}=$ $7.5 \times 10^{-7} \mathrm{~mol} \mathrm{l}^{-1}$.

aqueous layers were discarded by slowly opening the cock of the funnel. After removal of the layers, the floated ionassociate, which was completely adhering to the inner walls of the funnel, was dissolved in $5 \mathrm{ml}$ acetonitrile and the absorbance of the solution was measured at $509 \mathrm{~nm}$ against a reagent blank.

\section{Results and Discussion}

The reaction between $\mathrm{Fe}^{2+}$ and phen is a well-established process in which the resultant, a cationic dye reagent, $\mathrm{Fe}$ (phen) ${ }_{3}^{2+}$, is thoroughly stable over a wide range of $\mathrm{pH}$ and is conventionally used for iron determination. ${ }^{28}$ Similarly, the anion complex of $\mathrm{HgI}_{4}{ }^{2-}$ has a high stability constant in a weakly acidic medium. ${ }^{29}$ These two cationic and anionic complexes associate to form an ion-associate with high stability, which can be floated at the interface of the aqueous and a low polarity organic phase, such as $n$-heptane.

\section{Optimization}

The effect of $\mathrm{pH}$ on the flotation process was investigated over the range of 4.00 to 8.00 , just before the organic phase addition. As shown in Fig. 1, the absorbance achieved a

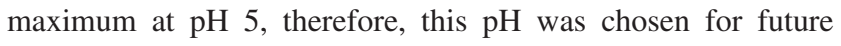
studies. Note that the absorbance decreases at the $\mathrm{pH}$ values other than 5 may be due to the instability that occurred for the ion-associate, which is subsequently attributed to the instability for ferroin and mercury iodide $\left(\mathrm{HgI}_{4}{ }^{2-}\right)$ complexes at low and high $\mathrm{pH}$ values, respectively.

The effect of iodide concentration on the formation of the ionassociate was studied in the range of $1.2 \times 10^{-4}$ to $7.2 \times 10^{-3} \mathrm{~mol}$ $1^{-1}$. Curve A in Fig. 2, indicates that the maximum absorbance occurs at the concentrations of iodide above $1.2 \times 10^{-3} \mathrm{~mol} \mathrm{l}^{-1}$. Since, increasing of the concentration of $\mathrm{Hg}(\mathrm{II})$ ion requires greater amount of iodide, the concentration of $2.4 \times 10^{-3} \mathrm{~mol} \mathrm{l}^{-1}$ was chosen for further investigations. Note that, due to the moderate tendency of the other halides to form the anionic complexes with $\mathrm{Hg}(\mathrm{II})$, if a considerable amount of such halides are present in the solution, the formation of $\mathrm{HgI}_{4}{ }^{2-}$ in the solution may be less than the expected value and, evidently, the flotation efficiency will be much decreased. Curve B in Fig. 2, represents the absorbance variation relevant to the performance of the flotation process in the presence of $1.6 \mathrm{~mol} \mathrm{l}^{-1}$ chloride, while the other conditions are similar to the previous investigations. As shown in Fig. 2, to eliminate the interference from these ions, a higher concentration of iodide is requested.

The effect of ferroin concentration on flotation of the ion-

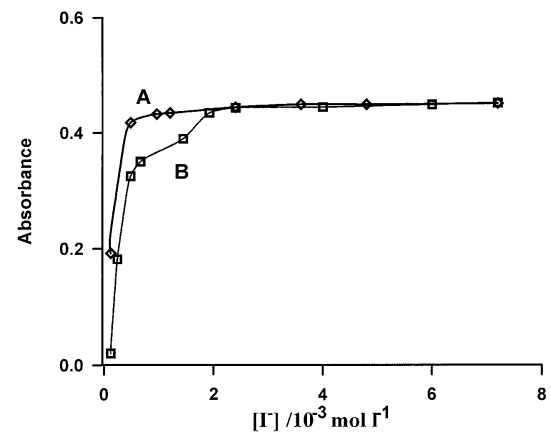

Fig. 2 Effect of iodide concentration on the determination of $\mathrm{Hg}$ (II) by the flotation method. The $\mathrm{pH}$ of the solution was adjusted to 5.00 , $C_{\text {Ferroin }}=3.12 \times 10^{-5} \mathrm{~mol} \mathrm{l}^{-1}$ and $C_{\mathrm{Hg}}=4.5 \times 10^{-7} \mathrm{~mol} \mathrm{l}^{-1}$ in all of the examinations. Curve $\mathrm{A}$, at the standard condition (absence of chloride ion); curve $\mathrm{B}$, at the presence of $1.6 \mathrm{~mol} \mathrm{l}^{-1}$ chloride.

associate was also studied over the concentration range of 3.12 $\times 10^{-5}$ to $3.12 \times 10^{-4} \mathrm{~mol}^{-1}$ in the solution. As shown in Fig. 3 , a maximum absorbance was obtained at a concentration of 6.25 $\times 10^{-6} \mathrm{~mol} \mathrm{l}^{-1}$, where further examination was performed. Decreasing the absorbance at concentrations greater than $1.25 \times$ $10^{-5}$ mol $1^{-1}$ of ferroin is probably due to increasing the ionassociate between iodide and ferroin in the blank. On the other hand, addition of an excess amount of ferroin causes the flotation process in the sample solution to delay. Since the proposed method should be applied to the real samples, all the experiments were repeated again in the presence of $1.6 \mathrm{~mol} \mathrm{l}^{-1}$ chloride and $6 \times 10^{-3} \mathrm{~mol} \mathrm{l}^{-1}$ iodide. With regards to that iodide at high concentration eliminated the interference from chloride presence at high concentration, it was not requested to a more or less concentration of ferroin.

\section{Effect of the organic phase}

Flotation of the ion-associate was investigated with several organic solvents. It was found that the absorbance depends on the solvent. For example, at the optimum conditions, the absorbance values for the flotation of $5 \times 10^{-7} \mathrm{~mol} \mathrm{l}^{-1} \mathrm{Hg}$ (II) with toluene, cyclohexane, $n$-hexane, and $n$-heptane were 0.328 , $0.462,0.400$, and 0.486 , respectively. In addition, more quick separation between the phases was observed using $n$-heptane. Thus, it was chosen for the further investigations.

\section{Effect of volume of the aqueous and organic phases}

The flotation process can be carried out quantitatively, when the volume of the aqueous solution containing $\mathrm{Hg}$ (II) was varied over $50-800 \mathrm{ml}$. The reproducible results were obtained under the volume up to $500 \mathrm{ml}$; however, at higher volumes the reproducibility was diminished.

The volume of the organic phase for the accurate performance of the flotation process was also investigated and we found that a $500-\mathrm{ml}$ aqueous phase requires $40 \mathrm{ml}$ of $n$-heptane as the organic phase.

\section{Conformity with Beer's law and figures of merit}

Under the optimum conditions, a linear calibration curve was obtained for $\mathrm{Hg}$ (II) over the range of $3.2 \times 10^{-8}$ to $9.5 \times 10^{-7} \mathrm{~mol}$ $1^{-1}$. The correlation coefficient $\left(R^{2}\right)$ was 0.9987 , showing a good linearity of the calibration curve. The apparent molar absorptivity at $509 \mathrm{~nm}$ was $1 \times 10^{6} 1 \mathrm{~mol}^{-1} \mathrm{~cm}^{-1}$ for a $500 \mathrm{ml}$ aliquot of the aqueous phase and a path length of $1 \mathrm{~cm}$. The RSD obtained for $3.19 \times 10^{-7} \mathrm{~mol} \mathrm{l}^{-1}$ of $\mathrm{Hg}$ (II) was $1.9 \%$ and the detection limit is defined as the sample concentration giving a 


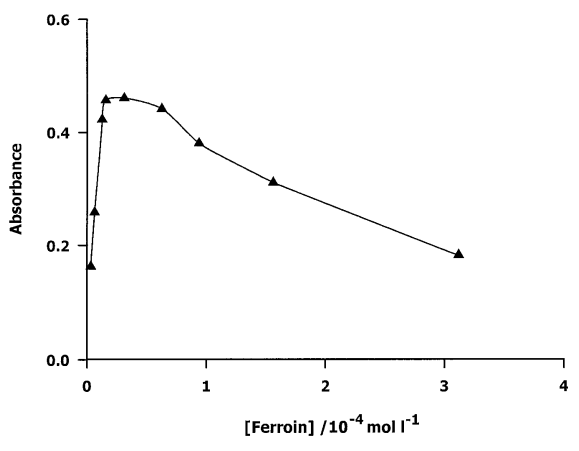

Fig. 3 Effect of ferroin concentration on the determination of $\mathrm{Hg}(\mathrm{II})$ by the flotation method at the conditions where the $\mathrm{pH}$ of the solution was adjusted to $5.00, C_{\mathrm{KI}}=1.2 \times 10^{-3} \mathrm{~mol} \mathrm{1}^{-1}$, and $C_{\mathrm{Hg}}=4.5$ $\times 10^{-7} \mathrm{~mol} \mathrm{l}^{-1}$.

signal equal to the blank average signal (25 blank) plus three times the standard deviation of the blanks was found to be $6.2 \times$ $10^{-9} \mathrm{~mol} \mathrm{l}^{-1}$.

\section{Effect of foreign ions}

A $500 \mathrm{ml}$ solution containing $32 \mu \mathrm{g}$ of $\mathrm{Hg}(\mathrm{II})\left(3.19 \times 10^{-7} \mathrm{~mol}\right.$ $1^{-1}$ ) and various amounts of foreign ions were treated as described in the procedure. The results are given in Table 1. It is observed that almost all of the cations and anions except $\mathrm{Ag}^{+}$, $\mathrm{Cd}^{2+}, \mathrm{Fe}^{3+}$, and $\mathrm{Cu}^{2+}$ are tolerated at high concentrations. The interference of $\mathrm{Ag}^{+}$may be due to form a moderately stable anion complex with iodide, similar to $\mathrm{Hg}(\mathrm{II})$. In contrast, the interferences of $\mathrm{Cd}^{2+}$ and $\mathrm{Cu}^{2+}$ are attributed to more stable complexes with phen. In addition, it is assumed that the iodide ions could be oxidized by $\mathrm{Fe}^{3+}$ ions if present at high concentration. The interference from $\mathrm{Cd}^{2+}, \mathrm{Cu}^{2+}$ and $\mathrm{Fe}^{3+}$ were sufficiently eliminated by $0.01 \mathrm{~mol}^{-1}$ EDTA as a masking agent. The interference of $\mathrm{Ag}^{+}$is more serious than that of the other ions. Fortunately, the concentration of $\mathrm{Ag}^{+}$is very low in an ordinary real sample, and $\mathrm{Ag}^{+}$is not a serious interferent on the determination of $\mathrm{Hg}(\mathrm{II})$ in practical analysis of the real samples. ${ }^{30}$

\section{Application to real samples}

The proposed method was applied for the determination of $\mathrm{Hg}$ (II) in several water samples, including tap water, synthetic seawater $^{31}$ and synthetic wastewater. ${ }^{27}$ Each of the samples were spiked with several known amounts of $\mathrm{Hg}(\mathrm{II})$. The recovery of the spiked $\mathrm{Hg}(\mathrm{II})$ was in the range of $93.4-105.9 \%$, which demonstrated that the proposed method is reliable (Table 2 ). In treatment with seawater, since the concentration of $\mathrm{Cl}^{-}$is very high, the iodide concentration was increased up to 5 times of the normal case as discussed earlier in the optimization part. The slopes of the calibration graphs prepared by the standard curve method for the water samples were found to be almost identical with that of the standard addition plot. Hence, the standard curve method was used in the determination of various samples.

The accuracy of the proposed method was checked by comparing the sample analysis results with those obtained by a well-established method, such as extraction-spectrophotometry with dithizone. ${ }^{32}$ As detailed in Ref. 32, the mercury in a 500 $\mathrm{ml}$ water sample was extracted into a $25 \mathrm{ml}$ aliquot of $\mathrm{CHCl}_{3}$-dithizone solution. The extraction was repeated three times and the total extracted solution was available for measurement of the absorbance. The analytical results for
Table 1 Tolerance limits for foreign ions in $3.19 \times 10^{-7} \mathrm{~mol} \mathrm{l}^{-1}$ $\mathrm{Hg}(\mathrm{II})$ in a $500-\mathrm{ml}$ solution

\begin{tabular}{cl}
\hline $\begin{array}{c}\text { Mole ratio of interfering } \\
\text { ion to } \mathrm{Hg}(\mathrm{II})\end{array}$ & \multicolumn{1}{c}{ Ion } \\
\hline 5000 & $\mathrm{Na}^{+}, \mathrm{K}^{+}, \mathrm{NH}_{4}{ }^{+}, \mathrm{Mg}^{2+}, \mathrm{Ca}^{2+}, \mathrm{Ba}^{2+}$, \\
& $\mathrm{Cd}^{2+}, \mathrm{Co}^{2+}, \mathrm{Cu}^{2+},{\mathrm{a} e^{2+}, \mathrm{Mn}^{2+},} \mathrm{Ni}^{2+}, \mathrm{Pb}^{2+}, \mathrm{Zn}^{2+}, \mathrm{Al}^{3+}, \mathrm{Cr}^{3+}, \mathrm{Fe}^{3+},{ }^{a}$ \\
& $\mathrm{~F}^{-}, \mathrm{Cl}^{-}, \mathrm{Br}^{-}, \mathrm{SCN}^{-}, \mathrm{ClO}_{4}^{-}$, \\
& $\mathrm{CH}_{3} \mathrm{COO}^{-}, \mathrm{CO}_{3}{ }^{2-}, \mathrm{SO}_{4}{ }^{2-}$ \\
& $\mathrm{C}_{2} \mathrm{O}_{4}^{2-}$ \\
& $\mathrm{Pb}^{2+}, \mathrm{Cu}^{2+}$ \\
1000 & $\mathrm{Fe}^{3+}$ \\
100 & $\mathrm{Ag}^{+}, \mathrm{Cd}^{2+}$ \\
\hline
\end{tabular}

a. Tolerated after masking with EDTA, which $5 \mathrm{ml}$ of $0.1 \mathrm{M}$ solution was added to the solution before the flotation process.

Table 2 Analytical data of mercury determination in $500 \mathrm{ml}$ of tap water and of synthetic seawater by both the present method and extraction-spectrophotometry with dithizone

\begin{tabular}{|c|c|c|c|c|c|}
\hline \multirow[b]{2}{*}{ Sample } & \multirow{2}{*}{$\begin{array}{c}\text { Spiked/ } \\
\mu \mathrm{g}\end{array}$} & \multicolumn{4}{|c|}{ Measured/ $\mu \mathrm{g}^{\mathrm{a}}$} \\
\hline & & $\begin{array}{l}\text { This } \\
\text { method }\end{array}$ & $\begin{array}{c}\text { Recovery, } \\
\%\end{array}$ & $\begin{array}{l}\text { Ext. } \\
\text { method }\end{array}$ & $\begin{array}{c}\text { Recovery, } \\
\% \\
\end{array}$ \\
\hline Tap & 32.00 & $32.68( \pm 0.07)$ & 102.1 & $32.96( \pm 0.08)$ & 103.0 \\
\hline \multirow{2}{*}{ water } & 16.00 & $16.95( \pm 0.07)$ & 105.9 & $16.60( \pm 0.09)$ & 103.8 \\
\hline & 8.00 & $8.48( \pm 0.08)$ & 106.0 & $8.34( \pm 0.12)$ & 104.2 \\
\hline Synth. & 32.00 & $32.29( \pm 0.08)$ & 100.9 & $33.56( \pm 0.11)$ & 104.9 \\
\hline waste- & 16.00 & $16.21( \pm 0.07)$ & 101.3 & $16.96( \pm 0.09)$ & 106.0 \\
\hline water & 8.00 & $8.17( \pm 0.09)$ & 102.1 & $8.64( \pm 0.12)$ & 108.0 \\
\hline Synth. & 32.00 & $30.87( \pm 0.08)$ & 96.5 & $30.77( \pm 0.07)$ & 96.15 \\
\hline Seawater & r 16.00 & $15.66( \pm 0.08)$ & 97.9 & $15.40( \pm 0.09)$ & 96.25 \\
\hline & 8.00 & $7.52( \pm 0.10)$ & 94.0 & $7.35( \pm 0.14)$ & 91.9 \\
\hline
\end{tabular}

a. The results are reported as the average values from five samples measurements.

various samples are listed in Table 2. The concentration of $\mathrm{Hg}$ (II) determined by the proposed method were in good agreement with those obtained by the dithizone method. The RSD of this method, when applied to the above samples was in the range of 1.9 to $2.5 \%$, whereas the RSD of the dithizone method was in the range of 2.5 to $3.7 \%$. These results showed the applicability of this method for the determination of $\mu \mathrm{g}^{-1}$ level $\mathrm{Hg}(\mathrm{II})$ in various types of environmental water samples.

\section{Conclusion}

This method has good sensitivity and selectivity for the determination of trace amount of $\mathrm{Hg}$ (II) in various types of water samples. In comparison with the well-known dithizone extraction method that was time-consuming and tedious and used a harmful solvent, this method is free of those limitations. It is easier, fast, and starts from the organic phase that is not so toxic. In addition, the organic phase can be used repeatedly without any purification; hence, the method has no problem in view of the environmental pollution. The stability of the ferroin solution is infinitely longer than that of the dithizone solution. Therefore, the reproducibility is better than the dithizone method. The detection limit, recovery yields and RSD of the method are satisfactorily comparable with the values from 
advanced instrumental methods, such as GFAAS and ICP-AES, so that the $\mu \mathrm{g} \mathrm{l}^{-1}$ level of $\mathrm{Hg}$ (II) can be easily determined by this method, without any complicated devices or procedures.

\section{Acknowledgements}

We wish to acknowledge financial support from the complementary education management of Birjand University.

\section{References}

1. P. O'Neil, “Mercury in Environmental Chemistry”, 2nd ed., 1995, Chapman and Hall, London.

2. D. Karunasagar, J. Arunachalam, and S. Gangadharan, J. Anal. At. Spectrom., 1998, 13, 679.

3. E. Saouter, Anal. Chem., 1994, 66, 2031.

4. I. Gelaude, R. Dams, M. Resano, F, Vanhaecke, and L. Moens, Anal. Chem., 2002, 74, 3833.

5. S. Rapsomankis and P. Craig, Anal. Chim. Acta, 1991, 248, 563.

6. R. Fischer, S. Rapsomankis, and M. O. Andreae, Anal. Chem., 1993, 65, 763 .

7. C. M. Tseng, A. De Diego, F. M. Martin, D. Amouroux, and O. F. X. Donard, J. Anal. At. Spectrom., 1997, 12, 743.

8. M. Navarro and M. C. Lopez, Anal. Chim. Acta, 1992, 257, 155.

9. G. Schnitzer, A. Soubelet, and C. Chafey, Microchim. Acta, 1995, 119, 199.

10. J. L. Manzoori, M. H. Sorouraddin, and A. M. H. Shabani, J. Anal. At. Spectrom., 1998, 10, 1017.

11. G. Tao, S. N. Wille, and R. E. Sturgeon, J. Anal. At. Spectrom., 1999, 14, 1929.

12. A. Shafawi, L. Ebdon, M. Foulkes, P. Stockwell, and W. Corns, Analyst [London], 1999, 124, 185.

13. P. Ugo, L. Moretto, P. Bertochello, and J. Wang, Electroanalysis, 1998, 10, 1017.
14. W. Huang and S. Zhang, Anal. Sci., 2002, 18, 187.

15. P. R. Devi, T. Gangaiah, and G. R. K. Naidu, Anal. Chim. Acta, 1991, 12, 533.

16. M. Caballero, R. Cela, and J. A. Peres-Bustamante, Talanta, 1990, 37, 275.

17. Z. Marczenko, Microchim. Acta, 1977, II, 651.

18. Z. Marczenko, CRC Crit. Rev. Anal. Chem., 1981, 11, 195.

19. Z. Marczenko and M. Jaroz, Analyst [London], 1981, 106, 751.

20. K. Kalinowski and Z. Marczenko, Microchim. Acta, 1985 , $I, 167$.

21. Z. Marczenko and K. Jankowski, Anal. Chim. Acta, 1985, 176,185 .

22. K. Kalinowski and Z. Marczenko, Anal. Chim. Acta, 1986, $186,331$.

23. L. Mathew, M. L. P. Reddy, T. R. Ramamohan, T. Prasad, C. S. P. Lyer, and A. D. Damodaran, Microchim. Acta, 1997, 127, 125.

24. V. Bhagavathy, T. Prasada Rao, and A. D. Damodaran, Anal. Chim. Acta, 1993, 280, 169.

25. M. Chamsaz, M. H. Arbab-Zavar, and M. S. Hosseini, Anal. Lett., 2000, 33, 1625 .

26. M. Chamsaz, M. S. Hosseini, and M. H. Arbab-Zavar, Chem. Anal. [Warsaw], 2004, 49, 241.

27. M. S. Hosseini and Y. Nasseri, Anal. Sci., 2003, 19, 1505.

28. A. A. Schilt, "Analytical Application of 1,10Phenanthroline and Related Compounds", 1st ed., 1969, Pergamon Perss, London.

29. J. A. Dean, "Lang's Handbook of Chemistry", 15th ed., 1999, McGraw-Hill, New York.

30. I. Gelaude, R. Dams, M. Resano, F, Vanhaecke, and L. Moens, Anal. Chem., 2002, 74, 3833.

31. F. W. Fifield and P. J. Haines, "Environmental Analytical Chemistry", 2nd ed., 2000, Blackwell Science, London.

32. "Standard Methods for Examination of Water and Wastewater", 15th ed., 1980, APHA-AWWA.WPCF, Washington, D.C. 